\title{
OPEN Modelling groundwater quality of the Athabasca River Basin in the subarctic region using a modified SWAT model
}

\author{
Tesfa Worku Meshesha ${ }^{1}$, Junye Wang ${ }^{1 \bowtie}$, Nigus Demelash Melaku ${ }^{1}$ \& Cynthia N. McClain ${ }^{2,3}$
}

Groundwater is a vital resource for human welfare. However, due to various factors, groundwater pollution is a paramount environmental concern. It is challenging to simulate groundwater quality dynamics with the Soil and Water Assessment Tool (SWAT) because it does not adequately model nutrient percolation processes in the soil. The objectives of this study were to extend the SWAT module to simulate groundwater quality for the parameters nitrate and Total Dissolved Solids (TDS). The results of the SWAT model for the Athabasca River Basin in Canada revealed a linear relationship between observed and calculated groundwater quality. This result achieved satisfactory values for coefficient of determination $\left(R^{2}\right)$, Nash-Sutcliffe efficiency (NSE), and percent bias (PBIAS). For nitrate, the model performance measures $R^{2}$ ranged from $0.66-0.83$ during calibration and NSE from $0.61-0.83$. $R^{2}$ is 0.71 during validation and NSE ranged from $0.69-0.75$. Likewise, for TDS, the model performance measures $R^{2}$ ranged from $0.61-0.82$ during calibration and from $0.58-0.62$ during validation. When coupled with soil zone and land surface processes, nitrate and TDS concentrations in groundwater can be simulated with the SWAT model. This indicated that SWAT may be helpful in evaluating adaptive management scenarios. Hence, the extended SWAT model could be a powerful tool for regional-scale modelling of nutrient loads, and to support and effective surface and groundwater management.

Groundwater is a vital resource for sustainable social and economic development around the world ${ }^{1,2}$. Stored groundwater is generally purified and filtered during infiltration through natural soils and sediments ${ }^{3,4}$. Therefore, the quality and quantity of groundwater storage tends to be more stable than surface water. Thus, majority of people in the world primarily depend on groundwater for their drinking water ${ }^{5}$. It is reported that groundwater provides drinking water for $>1.5 \mathrm{~b}$ people and supports approximately $40 \%$ of agriculture in the form of irrigation ${ }^{6}$. Therefore, protecting groundwater resources, including efficient use and conservation measures, are an important strategy of water resources plan in both developing and developed countries.

However, natural processes, anthropogenic activities, and climate change significantly influence the quality and quantity of groundwater. In many world watersheds, lakes, rivers, wetlands and the associated ecosystems have experienced impacts and thus, the vitality, availability, quality and quantity of these water resources face serious threats. Elevated concentrations of chemical elements and biological constituents exist in the environment, and depending on geo-environmental backgrounds, water pollutants may exhibit spatial and temporal variations $s^{7,8}$. Anthropogenic processes, such as discharge of untreated sewage water to water bodies, fertilization, and over exploitation, have changed groundwater quantity and quality ${ }^{9-11}$, leading to soil-water and air pollution ${ }^{12}$. For example, excessive application of chemical fertilizer could result in groundwater contamination $^{10,13,14}$. Nitrogen leaching, namely the downward transport and percolation of nitrate from the root zone to the soil layers, is one of the aggravating causes for groundwater contamination, especially in irrigated areas $^{15,16}$. However, it is still unclear how the anthropogenic and natural factors drive the change in the fluxes and storages of water, and associated groundwater quality. Consequently, a linked understanding of surface water and groundwater quality over space and time is critical for the assessment and management of such vital resources and ecosystems services, particularly in arid and semi-arid regions ${ }^{17-20}$.

\footnotetext{
${ }^{1}$ Athabasca River Basin Research Institute (ARBRI), Athabasca University, 1 University Drive, Athabasca, AB T9S 3A3, Canada. 'Environment and Parks, Government of Alberta, 3535 Research Road NW, Calgary, AB T2L 2K8, Canada. ${ }^{3}$ Department of Geoscience, University of Calgary, 2500 University Drive NW, Calgary, AB T2N 1N4, Canada. ${ }^{\varpi}$ email: junyewang@athabascau.ca
} 
Groundwater assessment is complex, involving identification of surface and groundwater quality and quantity drivers and the occurrence, interaction and determination of the probability of the occurrence of such problems $s^{21,22}$. In order to simulate both saturated and unsaturated water flow from the porous media, many widely used physical models of Richards equations has been developed by many researchers ${ }^{23-25}$. This approach could capture the groundwater dynamics ${ }^{25}$ but lacks representation of land surface information like vegetation cover. In order to address this limitation, scientists have developed various hydrological models to simulate interactions among water, soil, and vegetation ${ }^{26}$ modified the SWAT model to calculate lateral and vertical flows through soil layers to improve representations recharge of groundwater mountain region of Germany. VazquezAmábile et al. ${ }^{27}$ applied advanced redox zonation of an alluvial aquifer using data fusion and multivariate geostatistics. They indicated that incorrect wastewater management could cause the organic matter transfer from the eutrophicated surface-groundwater into to groundwater. Luo et al. ${ }^{28}$ modified SWAT model to simulate the change of soil moisture into groundwater and stream flow in the Muscatatuck River watershed. Baffaut et al. ${ }^{29}$ incorporated a groundwater module in the SWAT model version 2000 to simulate groundwater evaporation in the Yellow River basin. Watson et al. ${ }^{30}$ modified the SWAT groundwater module version 2005 to improve infiltration process from sinkholes to surface waters and to evaluate aquifer recharge in karst surroundings of the USA. Mckeown et al..$^{31}$ and Melaku et al. ${ }^{32}$ incorporated an algorithm to consider the effect of slope and aspect on incoming solar radiation into the SWAT model in the forested watershed in the Boreal plain. Meshesha et al. ${ }^{33}$ modified the evapotranspiration in the SWAT model to account for two-way groundwater-surface water movement in estimating the groundwater table in Lethbridge and Barons area. Meshesha et al. ${ }^{34}$ extended the hydrological model for cold climate regions in order to quantify bacterial fluxes and its effect on surface water quality, and Kim et al..$^{35}$ evaluated water quality consequently effect on aquatic environment. Guzman et al. ${ }^{36}$, Nguyen et al. ${ }^{37}$ and $\mathrm{Ng}$ et al. ${ }^{38}$ coupled the SWAT model with the three-dimensional groundwater flow model (MODFLOW) to represent groundwater flow. The main drawback of the coupled model is that the users must establish numerously formatted variables that properly fit ${ }^{39}$. Although these coupled SWAT-MODFLOW models enable simulation of groundwater recharge, aquifer evapotranspiration and groundwater levels, it is a big challenge to find a way to dynamically simulate water quality when coupling SWAT source code with MODFLOW code because the two models may have different definitions, formats and arrays of water quality variables. Therefore, such a coupled approach of the two different models requires modification of core codes, such as definitions of variables and its arrays in simulating ground water quality ${ }^{40}$. Although a plethora of models have been developed in the past few decades, most of the modelling experiences have focused mainly on understanding on the spatio-temporal groundwater storage. Appraisal of distribution and mitigation of chemical elements in the groundwater using SWAT model is still lacking.

Economic activity and human settlement in the Athabasca river basin (ARB) are being varied, and the basin is culturally vibrant and diverse as the homes for more than 150,000 residents with $13 \%$ of Aboriginal peoples ${ }^{40}$. However, the development of agriculture, recreation, forestry, conventional situ oil and gas, and mining can negatively affect the health of the river basin. Developing reliable groundwater quality model as a tool could provide a very useful insight on the potential mitigation of nonpoint source pollution into groundwater in river basins, which are especially important in assessing the pervasive high nutrients loadings from fertilization and manure application. The main objectives of this study are to: (i) improve representation of groundwater quality parameters in a groundwater nutrient module to account for nitrate $\left(\mathrm{NO}_{3}^{-}\right)$and total dissolved solids (TDS) in the SWAT model ${ }^{41}$; (ii) assess the effect to $\mathrm{NO}_{3}{ }^{-}$and TDS on groundwater quality status in the Athabasca River Basin; and (iii) evaluate SWAT model sensitivity and uncertainty analysis to understand the possible limitations, and recommend forthcoming directions in model formulation efforts.

\section{Methods and materials}

The study area. The research area is in Athabasca River Basin (ARB), which is located in the central part of the province of Alberta in the subarctic region (Fig. 1). Athabasca River is the second largest river in Alberta, and the largest undammed river. The mean annual discharges in cubic decameters ( $\mathrm{dam}^{3}=1000$ cubic meters) at the points along the river are 2,790,000 $\mathrm{dam}^{3}$ at Jasper 13,600,000 dam 3 at Athabasca. The river basin in general have substantial economic contribution in Canada by providing reliable freshwater supply to the people as well as for various industries, such as oil sands mining and pulp mills ${ }^{42}$. The main land cover type of the ARB is the boreal forest, which shares $82 \%$ of the total land; agriculture shares $9.5 \%$, which is in the central portion of the watershed (i.e., Pembina, Lesse Slave, McLeod and upper parts). Overall forest, agriculture, traditional oil and gas extraction, oil sand mining, and coal mining are the major industries of the $\mathrm{ARB}^{41}$. Mean annual precipitation of the area ranges from $300 \mathrm{~mm}$ in the lower portion of the river basin to $>1000 \mathrm{~mm}$ from the headwaters, while the mean temperature ranges $1.8-5.1^{\circ} \mathrm{C}^{43}$.

The major aquifer types include near-surface sands, buried channels and valleys, Paskapoo aquifers, and bedrock aquifers, which characterize the basin with primary and/or secondary porosities ${ }^{42}$. In this area, groundwater within unconsolidated surficial deposits consist of a mixture of a preglacial and glacial sand and gravel aquifers. In the Athabasca River Basin, groundwater recharge is spatially variable, and groundwater contributes baseflow to rivers and streams $s^{44,45}$. This region has extensive wetlands, including groundwater-fed wetlands (fens), and one of the world's most ecologically significant wetlands designated by the Ramsar Convention. The ecology within the watershed is diverse as a result of the different natural regions. As the major river system, the ARB is influenced by a variety of climate, terrain and landscape characteristics found within its basin. The seasonality of climatic conditions is a major influence on river flow conditions.

Soil and Water Assessment Tool (SWAT) description and application. The SWAT model is a river basin scale model, which is developed in order to quantify the impact of land management practices in large, 


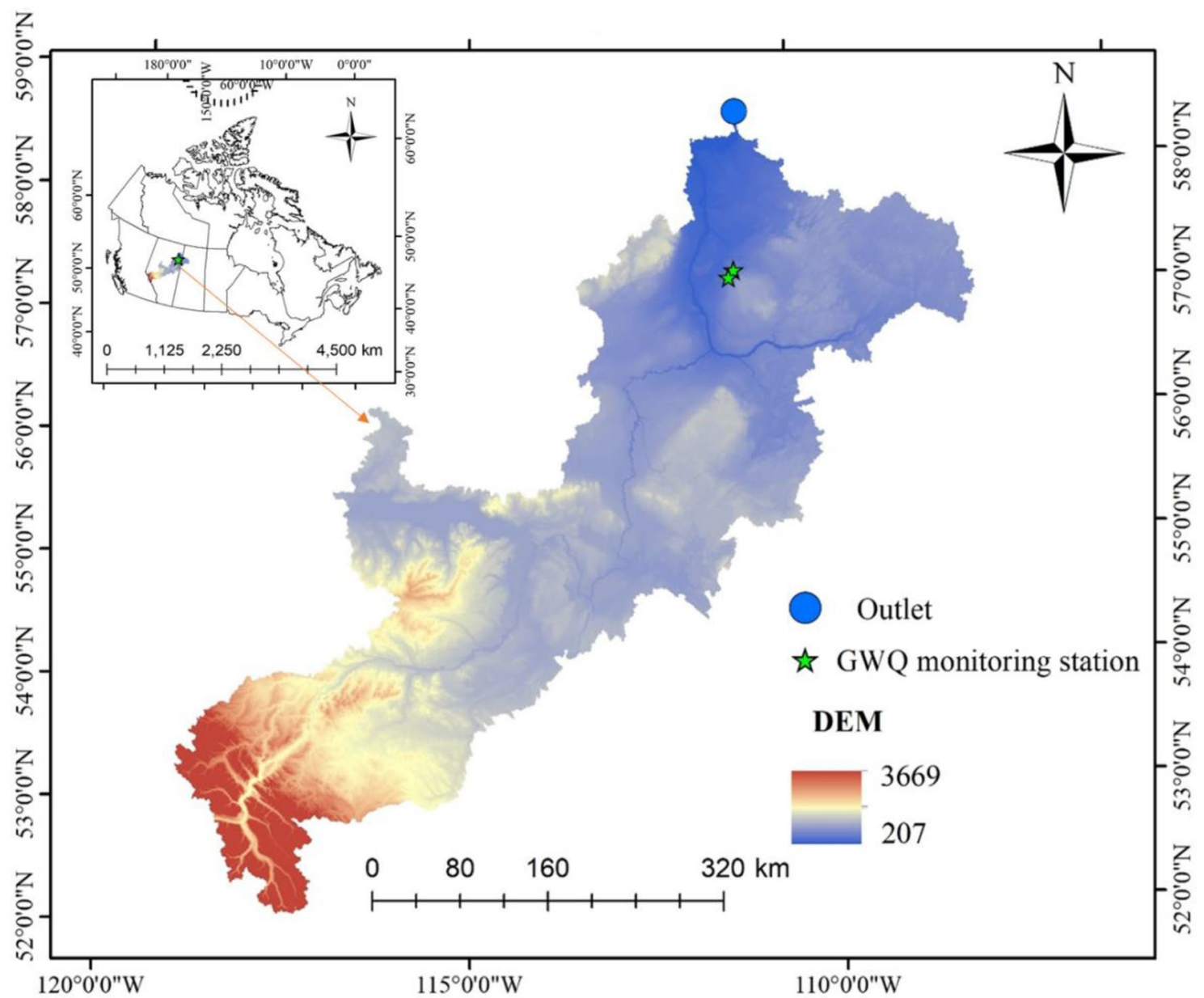

Figure 1. Geographical location of Athabasca River Basin (ARB), Canada. The DEM of the ARB shows the two water quality monitoring stations used for model calibration for this study. The map was generated using GIS \& RS (https://www.arcgis.com/index.html).

complex watersheds at daily time step ${ }^{46,47}$. It could be used for simulating the hydrological process, nutrient concentration, runoff generation, and sediment yield in the watershed under various landuse as well as soil scenario $^{46,48,49}$. Additionally, it is used for simulating the effects of climate change, landuse and management practices on the quantity and quality of water ${ }^{50}$.

The SWAT has been used for simulating the $\mathrm{N}$ cycle in soils and aquifer at shallow depth ${ }^{51,52}$. In the water and soil, the $\mathrm{N}$ processes is dynamic. It could be added to the soil in the form of manure, bacteriological fixation, residue, and rainfalls. It may be moved out from the soil through by plant uptake, volatilization, soil erosion, denitrification, and leaching. In the SWAT model, there are various types of $\mathrm{N}$ pools, including inorganic forms of nitrogen, and organic forms. $\mathrm{NO}_{3}{ }^{-}$may transport with runoff, percolation or lateral flow and recharge into the aquifer to the shallow depth from the soil profile. In addition, $\mathrm{NO}_{3}{ }^{-}$can move with groundwater flow to river channels or be carried out of the shallow aquifer into the soil zone during water deficiencies. The amount of nitrate carried by water is calculated by multiplying the concentration of nitrate in the mobile water fraction by the volume of water moving in each route. The amount of $\mathrm{NO}_{3}{ }^{-}$discharge depends on $\mathrm{NO}_{3}{ }^{-}$concentration in the soil-water domain. Nitrate uptake by plants has an inverse exponential relationship with depth ${ }^{47}$.

$$
\mathrm{NO}_{3 \operatorname{conc}, z}=7 * \exp \left(\frac{-z}{1000}\right)
$$

where $\mathrm{NO}_{3 \text { conc, } \mathrm{z}}$ refers to initial nitrate concentration $(\mathrm{mg} / \mathrm{kg})$ at the depth of $\mathrm{z}(\mathrm{mm})$. Only the parts of $\mathrm{NO}_{3}{ }^{-}$is mobile and therefore it available for the discharge through the tiles. To calculate the concentration of nitrate in the mobile water fraction, the following equation has been adopted from ${ }^{53,54}$.

$$
\operatorname{Conc}_{N O_{3, \text { mobile }}}=\frac{N O_{31 y}\left(1-\exp \left[-W_{\text {mobile }} /(1-\theta e) S A T_{1 y}\right]\right)}{W_{\text {mobile }}}
$$

where ConcN $\mathrm{O}_{\mathrm{O} \text {,mobile }}$ refers to $\mathrm{NO}_{3}{ }^{-}$concentration in the movable water at a given layer ( $\mathrm{kg} \mathrm{N} / \mathrm{ha}$ ), $\mathrm{W}_{\text {mobile }}$ represent the amount of water lost by runoff, percolation or side flow in the layer $\left(\mathrm{mm} \mathrm{H}_{2} \mathrm{O}\right), \theta$ e represent fraction of porosity from which anions are excluded, $\mathrm{SAT}_{1 \mathrm{y}}$ is saturated water content in the soil layer $\left(\mathrm{mm} \mathrm{H}_{2} \mathrm{O}\right)$. To 


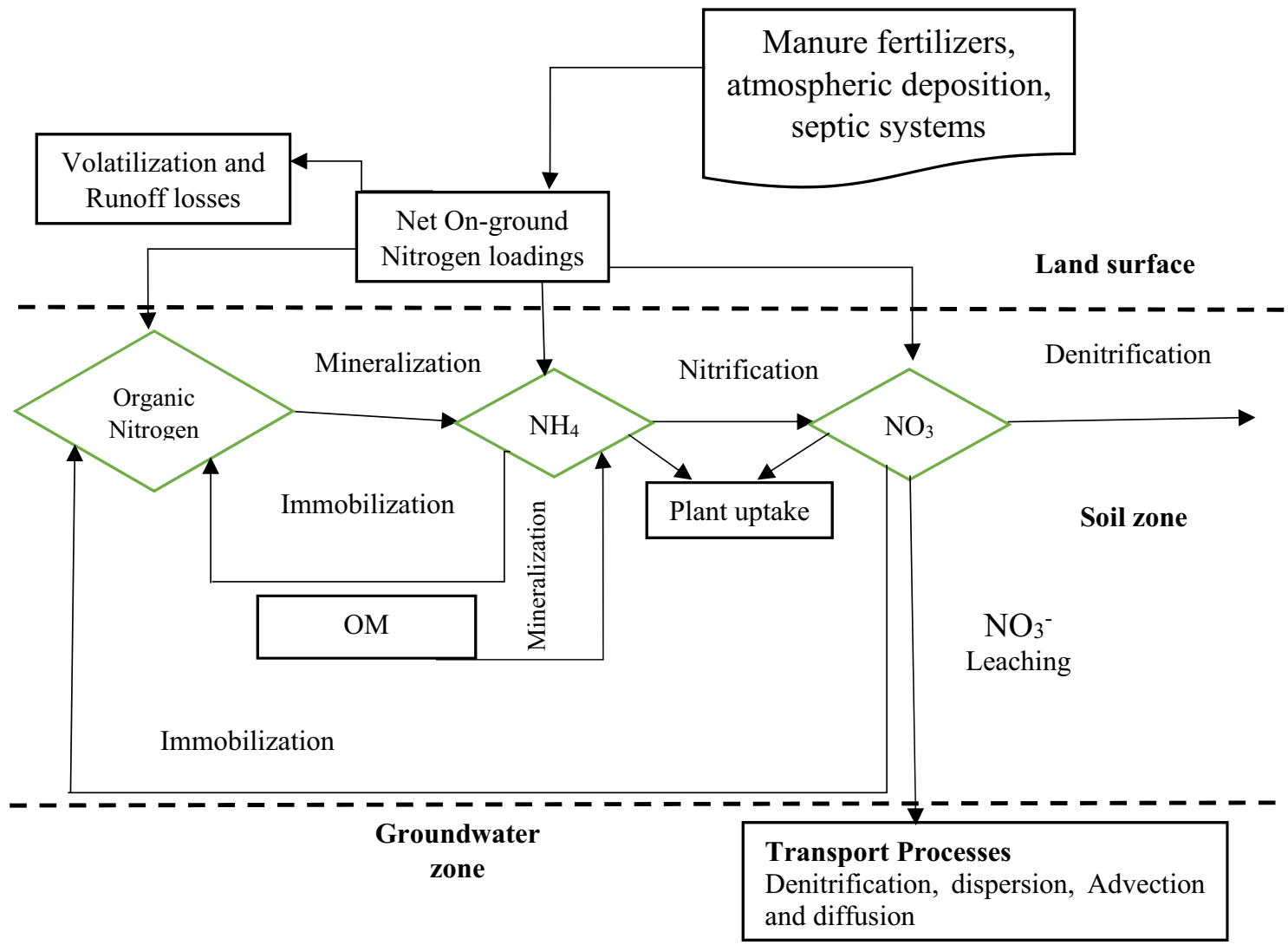

Figure 2. The conceptual framework demonstrating nitrate occurrence in the groundwater (adopted from Almasri $\left.{ }^{9}\right)$.

obtain the transport of nitrate with runoff, percolation, and lateral flow, the following generic equation has been adopted from ${ }^{55}$.

$$
\mathrm{NO}_{3}=\beta_{\mathrm{NO}_{3}} \operatorname{conc}_{\mathrm{NO}_{3, \text { mobile }}} Q_{x}
$$

where $\mathrm{NO}_{3}{ }^{-}$represents the $\mathrm{NO}_{3}{ }^{-}$removed by the physical transport (i.e., lateral flow, runoff, percolation) (kg $\left.\mathrm{ha}^{-1}\right) ; \beta_{\mathrm{NO} 3}$ is the concentration of $\mathrm{NO}_{3}{ }^{-}$in the mobile water for the top $10 \mathrm{~mm}$ of soil $/ \mathrm{kg} \mathrm{ha}^{-1}$ considering both surface and subsurface lateral flow in the top layer; and $Q_{x}$ is the water physical transport (i.e. $Q_{\text {surf }}, Q_{\text {lat }}, Q_{\text {perc }}$ ). The $\mathrm{NO}_{3}{ }^{-}$, that percolates to the shallow aquifer from the soil profile may remain in the aquifer, or it may move with groundwater flow into the main river channel or into the deep aquifer. Organic transport of $\mathrm{N}$ with sediment is obtained as a concentration function proposed by ${ }^{56}$ and later applied by ${ }^{57}$ to the separated runoff events. Estimating the daily organic $\mathrm{N}$ runoff loss is on the basis of concentration of organic $\mathrm{N}$ in the top soil layer, the sediment yield and the enrichment ratio of the organic nitrogen in sediment to organic $\mathrm{N}$ in soil layer ${ }^{51}$ see Fig. 2). In the SWAT model, water quality procedures integrate essential interactions and relationships used in the QUAL2E mode ${ }^{58}$, which includes the major interactive factors such as the nutrient cycles, benthic oxygen demand, and algae production.

TDS is all the dissolved chemicals in the water $(\mathrm{mg} / \mathrm{L})$. It can be obtained by adding all the concentrations from chemical analysis or can be measured as weight of the residue after a volume of water has been evaporated to dryness. Typically, the concentration of TDS increases with the sample depth that groundwater has traveled from the recharge area to the sample sites. High nutrient concentration in the groundwater shows contamination form different sources of pollution ${ }^{59}$.

Groundwater module in the SWAT model. Existing SWAT model divides underground saturated aquifer into shallow and deep aquifer. The balance of water in the shallow aquifer can be described ${ }^{47,60}$ :

$$
S_{s h}^{i}=S_{s h}^{i-1}+W_{r g, s h}^{i}-Q_{g w, s h}^{i}-W_{r p}^{i}-W_{p u m p, s h}^{i}
$$

where, $S_{s h \text { and }}^{i} S_{s h}^{i-1}$ is the volume of water stored in the shallow aquifer on the day i and i-1, respectively, $Q_{g w, s h}^{i}$ is refers to the groundwater from the shallow aquifer on the day $i, W_{r g, s h}^{i}$ shows the volume of recharge which is entering the shallow aquifer on the day $i, W_{r p}^{i}$ is indicates the amount of water entering to the soil for the evaporation as well as transpiration on the day $i, W_{p u m p, s h}^{i}$ is refers to the amount of water removed from the shallow aquifer in the form of pumping on the day $i$. Assuming that the variation in groundwater is linearly correlated to the water table, the flow of groundwater can be represented by the following equations: 


$$
Q_{g w, s h}^{i}=\alpha_{g w, s h} s_{s h}^{i}
$$

where, $\alpha_{g w, s h}$ refers to the groundwater recession constant of the shallow aquifer. Groundwater from the shallow aquifer contributed to the river on day $i$ is obtained as:

$$
\begin{gathered}
Q_{g w}^{i}=Q_{g w}^{i-1} \cdot e^{-\alpha_{g w} \cdot \Delta t}+W_{r g, s h} \cdot\left(1-e^{-\alpha_{g w} \cdot \Delta t}\right) \quad \text { if } S_{s h}>S_{s h t h r, q} \\
Q_{g w}^{i}=0 \quad \text { if } S_{s h}<S_{s h t h r, q}
\end{gathered}
$$

where $S_{s h t h r, q}$ is a threshold value above which the stored groundwater flows to river channels, $\alpha_{g w}$ is the base flow recession constant, $W_{r g, s h}$ is the amount of recharge entering the shallow aquifer on day $i$, and $\Delta t$ is the time step.

The volume of recharge entering the shallow aquifer on day $i$ is obtained using the following equations:

$$
\begin{gathered}
W_{r g, d p}^{i}=\left(\beta_{d p}\right) W_{r g}^{i} \\
W_{r g, s h}^{i}=\left(1-\beta_{d p}\right) W_{r g}^{i} \\
W_{r g}^{i}=\left(1-e^{-\frac{1}{\delta g w}}\right) W_{s e e p}^{i}+\left(1-e^{-\frac{1}{\delta g w}}\right) W_{r g}^{i-1}
\end{gathered}
$$

where $W_{\text {seep }}^{i}$ is the total amount of water exiting the bottom of the soil profile on day $i$, and $\delta_{g w}$ is the drainage time of the overlying geologic formations. $W_{r g}^{i}$ and $W_{r g}^{i-1}$ are the amount of recharge entering the aquifers on day $i$ and $i-1$, respectively. $\delta_{g w}$ is estimated against observed data in water table level through simulating aquifer recharge.

Likewise, from the deep aquifer groundwater, which is contributed to the stream on the day, $i$ is obtained by:

$$
Q_{g w, d p}^{i}=Q_{g w, d p}^{i-1} e^{-\alpha_{g w, d p}}+W_{r g, d p}^{i}\left(1-e^{-\alpha_{g w, d p}}\right)
$$

where $Q_{g w, d p}^{i}$ and $Q_{g w, d p}^{i-1}$ refer to flow of groundwater from the deep aquifer into the stream on day $i$ and $i-1$, respectively, and $\alpha_{g w, d p}$ is the groundwater recession constant of the deep aquifer.

Due to complexity of groundwater, we separate the shallow aquifer into a lower aquifer and an upper aquifer in the groundwater module of SWAT model to improve the model accuracy, similar to Shao et al. ${ }^{58}$. Thus, the groundwater flow in Eq. (6) can be replaced using upper and lower aquifers as follows

$$
\begin{gathered}
Q_{g w, u}^{i}=Q_{g w, u}^{i-1} e^{-u}+W_{r g, u}^{i}\left(1-e^{-\alpha_{g w, u}}\right) \\
Q_{g w, l}^{i}=Q_{g w, l}^{i-1} e^{-\alpha_{g w, l}}+W_{r g, l}^{i}\left(1-e^{-\alpha_{g w, l}}\right)
\end{gathered}
$$

where, $Q_{g w, l}^{i}$ and $Q_{g w, u}^{i}$ refers to flow of groundwater from lower and upper aquifer into the stream on the day $i$ respectively; where as $-\alpha_{g w, u}$ and $-\alpha_{g w, l}$ shows groundwater recession constant of the lower and upper aquifer respectively; $W_{r g, l}^{i}$ and $W_{r g, u}^{i}$ shows the volume of recharge entering into the lower and upper aquifer in the day $i$ respectively.

SWAT model setup. Delineation processes were done in ArcGIS. Based on soil types and landuse classes, the hydrological response unit (HRU) was defined, based on similar soil, similar landuse, and slope types. About 1370 HRUs were identified for the basins. Weather data, such as, temperature, rainfall, wind speed, humidity, and radiation observation were obtained from Alberta Environment and Parks. Groundwater well and water quality data (nitrogen species and TDS) at 1,300 different monitoring stations was obtained from Alberta Environment and Parks as shown in Fig. 1. Data availability is one of the most prominent factors which affect the model accuracy. Therefore, there were two monitoring stations with $>15$ samples for the selected parameters between 2004 and 2016 namely IOR-KRL-03 (ss) and IOR-KRL-04 (ss) monitoring stations. Both groundwater monitoring wells are completed in surficial sand aquifers at $3 \mathrm{~m}$ and $11 \mathrm{~m}$ respectively.

Model performance metrics and uncertainty analysis. Measured groundwater quality data for $\mathrm{NO}_{3}{ }^{-}$ and TDS were used for model calibration and validation. To evaluate model performance, coefficient of determination $\left(R^{2}\right)$, Nash-Sutcliffe efficiency (NSE), and percent bias (PBIAS) were used ${ }^{61}$. The descriptions of NSE, $R^{2}$, and PBIAS can be found in ${ }^{62}$ as follows:

$$
R^{2}=\left(\frac{\sum_{i=1}^{n}\left(O_{i}-O_{a v r}\right)\left(P_{i}-P_{a v r}\right)}{\sqrt{\sum_{i=1}^{n}\left(O_{i}-O_{a v r}\right)^{2}} \sqrt{\sum_{i=1}^{n}\left(P_{i}-P_{a v r}\right)^{2}}}\right)^{2}
$$




\begin{tabular}{|c|c|c|c|c|c|}
\hline Parameters & input & Description & Unit & Range & Fitted value \\
\hline Denitrification & CDN.bs & Denitrification exponential rate coefficient & NA & 0 to 3 & 2.5 \\
\hline Ground W. Nitrn & r_GWNO3.gw & Concentration of $\mathrm{NO}_{3}$ in groundwater & & -1 to 1 & 0.5 \\
\hline Nitrate Percoln. co & NPERCO.bsn & Nitrate percolation coefficient & & 0 to 1 & 0.223 \\
\hline Transport of nitrogen growth with sediment & ERORGN.hru & Organic nitrogen enrichment ratio & NA & 0 to 5 & 2.75 \\
\hline Shallow aquifer nitrate & HLIFE_NGW.gw & Half-life of nitrate-nitrogen in the shallow aquifer & Day $^{-1}$ & 0 to 200 & 116 \\
\hline Mineralization & CMN.bsn & Rate factor for humus mineralization of active organic nitrogen & NA & 0.0001 to 0.0003 & 0.000131 \\
\hline Nitrogen percolation & NPERCO.bsn & Percolation of nitrogen coefficient & NA & 0 to 1 & 0.5 \\
\hline Nitrogen settling rate & NSETLR1.1wq & Settling nitrogen rate & $\mathrm{m} /$ year & 1 to 150 & 30 \\
\hline $\mathrm{N}_{2}$ uptake & N_UPDIS.bsn & Distribution of nitrogen uptake parameter & NA & 1 to 31 & 28 \\
\hline Base flow & RCHRG_DP.gw & Groundwater recharge to deep aquifer & fr & 0 to 1 & 0.09 \\
\hline Base flow & REVAPMN.gw & Water depth in the shallow aquifer & $\mathrm{mm}$ & 0 to 500 & 196 \\
\hline Base flow & GW_DELAY.gw & Groundwater delay & $\mathrm{d}$ & 0 to 500 & 41 \\
\hline Base flow & GWQMN.gw & $\begin{array}{l}\text { Threshold depth of water in the shallow aquifer required fir return } \\
\text { flow to occur }\end{array}$ & $\mathrm{mm}$ & 0 to 1000 & 618 \\
\hline Base flow & GW_REVAP.gw & Groundwater revap coefficient & NA & 0.02 to 2 & 0.06 \\
\hline Lateral flow/infiltration & SOL_K.sol & hydraulic conductivity (Saturated) & $\mathrm{Mmh}^{-1}$ & -25 to +25 & 16 \\
\hline Lateral flow/infiltration & SOL_AWC.sol & water capacity of the soil layer (Availability) & $\mathrm{ft}$ & -25 to +25 & 10 \\
\hline Runoff & CN2.mgt1 & curve number for moisture condition II & NA & -15 to +15 & 10 \\
\hline Runoff & CH_N1.sub & Manning's rate for tributary channel & NA & 0.025 to 0.30 & 0.096 \\
\hline Base flow & ALPHA_BF.gw & Base flow alpha factor & $\mathrm{d}$ & 0 to 1 & 073 \\
\hline
\end{tabular}

Table 1. The ranges of parameters included prior and after model calibration.

$$
\begin{gathered}
N S E=1-\left[\frac{\sum_{i=1}^{n}\left(O_{i}-P_{i}\right)^{2}}{\left[\sum_{i=1}^{n}\left(O_{i}-O_{a v r}\right)^{2}\right]}\right] \\
\text { PBIAS }=\left[\frac{\left.\sum_{i=1}^{n} O b s_{i}-S i m_{i}\right) * 100}{\sum_{i=1}^{n} O b s_{i}}\right]
\end{gathered}
$$

where $O_{i}$ refers to the $i$ th observed value; $O_{a v r}$ is the average observed value; $P_{i}$ is the $i$ th simulated value; $P_{a v r}$ is average simulated value; $n$ is the number of time step (days in our case).

To examine the model performance, $\mathrm{NO}_{3}{ }^{-}$and TDS of groundwater quality have been compared with the observed data during calibration (2009-2012) and validation (2013-2015). In order to perform parameter sensitivity and uncertainty analysis, we used Sequential Uncertainty Fitting2 (SUFI-2) algorithm in the SWAT-CUP ${ }^{63}$. The program generated various parameter sets for these selected parameters from a specified range of values using the Latin-Hypercube sampling technique (Table 1). To identify the total predictive uncertainty band of the simulated results, the SWATCUP was run several times, each one identifying a narrow parameter range for each parameter listed in Table 1, up to the point where reasonable goodness-of-fit statistics values were attained.

\section{Results}

Sensitivity and uncertainty analysis. Sensitivity test analysis is to identify the most sensitive parameters that govern $\mathrm{NO}_{3}{ }^{-}$and TDS in groundwater (Table 1). The range of selected sensitive parameters are presented in Table 1. Some parameters are basin scale and others are basin-based parameters. The analysis of model sensitivity can be processed to find out the relative response of the SWAT model to the changes in relative value of specific model parameters. Hence, some parameters are sensitive to control the whole system processes as the most significant parameters. Here, the most sensitive parameters governing the groundwater parameters were assessed on the basis of the values obtained during primary model calibration. The CDN.bs, $\mathrm{r}_{-} \mathrm{GWNO}_{3}$.gW, HLIFE_NGW.gw, and NPERCO.bsn were ranked as the most sensitive parameters among the $\mathrm{NO}_{3}{ }^{-}$parameters. While NSETLR1.1wq and N_UPDIS.bsn were the sensitive parameters from the N parameters, that influenced the concentration. On the other hand, the parameters listed in Table 1 were the most sensitive for TDS, groundwater conditions, and surface runoff. The results of the sensitive analysis confirmed that measured input parameters have a substantial influence on the model prediction.

Model Calibration and Validation performance. Model calibration and validation are done after the sensitivity analysis. To compare the model performance, the simulated outputs were compared with observed value. Therefore, the daily $\mathrm{NO}_{3}{ }^{-}$and TDS from the groundwater monitoring stations IOR-KRL-03 (ss) and 


\begin{tabular}{|l|l|l|l|l|c|}
\hline \multirow{3}{*}{ Monitoring stations ID } & \multirow{4}{*}{ Performance measure } & $\mathrm{NO}_{3}{ }^{-}$ & \multicolumn{2}{l|}{ TDS } \\
\cline { 2 - 6 } & Calibration & Validation & Calibration & Validation \\
\hline \multirow{3}{*}{ IOR-KRL-03 (ss) } & NSE & 0.61 & 0.69 & 0.72 & 0.58 \\
\cline { 2 - 6 } & PBIAS & 7.32 & 6.31 & 9.34 & -6.72 \\
\cline { 2 - 6 } & $\mathrm{R}^{2}$ & 0.66 & 0.71 & 0.82 & 0.69 \\
\hline \multirow{3}{*}{ IOR-KRL-04 (ss) } & $\mathrm{NSE}$ & 0.83 & 0.75 & 0.48 & 0.62 \\
\cline { 2 - 6 } & PBIAS & 11.32 & 6.19 & 10.04 & 6.06 \\
\cline { 2 - 6 } & $\mathrm{R}^{2}$ & 0.83 & 0.71 & 0.61 & 0.67 \\
\hline
\end{tabular}

Table 2. Model performance assessment for the daily observed data.
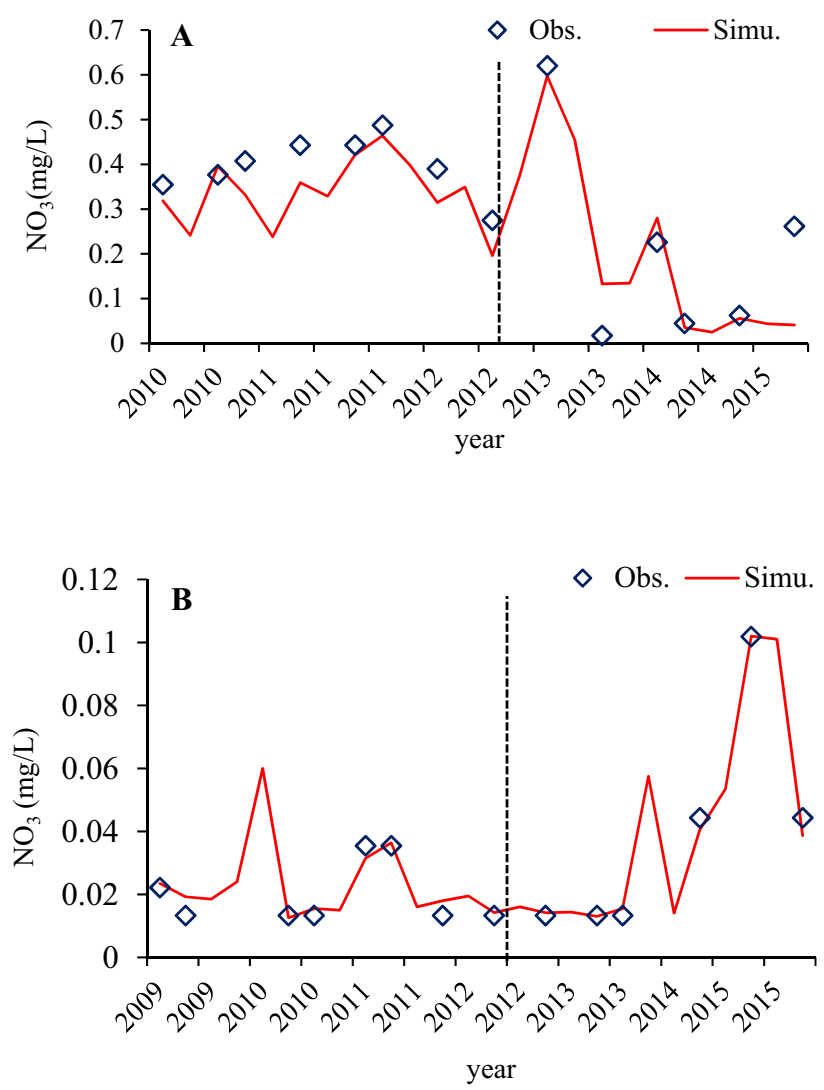

Figure 3. Comparison of daily observed and simulated groundwater quality parameter $\left(\mathrm{NO}_{3} / \mathrm{mg} / \mathrm{L}\right)$ at IORKRL-03 (SS) (A) and IOR-KRL-04 (SS) (B) monitoring stations.

IOR-KRL-04 (ss) from ARB were employed for the model calibration and validation to evaluate the model performance using SWATCUP which was recommended by Arnold et al. ${ }^{41}$. Based on the criteria of model performances rating, the value of PBIAS, NSE and $R^{2}$ during model calibration and validation were employed for evaluating the model performance. To calibrate the modified SWAT module, Latin-Hypercube One-factor At a Time (LH-OAT) was employed.

Table 2 summarizes the performance statistics of the model for the daily nutrient concentration simulations for two groundwater monitoring stations. Table 2 shows satisfactory to very good for both stations with an averaged $R^{2}$ of 0.74 for nitrate during calibration and 0.71 during validation. This confirmed that the model was able to capture the concentration of nutrients after model modification (Table 2 and Fig. 3). Therefore, the overall model performance of the new SWAT module for the daily nutrient concentration simulations was in acceptable range of model calibration and validation in the ARB. In contrast, a lower model performance for TDS simulation was observed at both monitoring stations, for which the value of NSE is found to be 0.58 during validation at IOR-KRL-03 (ss) and 0.48 during calibration at IOR-KRL-04 (ss).

Nitrate $\left(\mathrm{NO}_{3}{ }^{-}\right)$. Nitrate calibration processes happened in a nitrogen percolation coefficient of 0.5 , with a denitrification threshold of water content and exponential rate of denitrification coefficient of 2.5 (Table 1). 

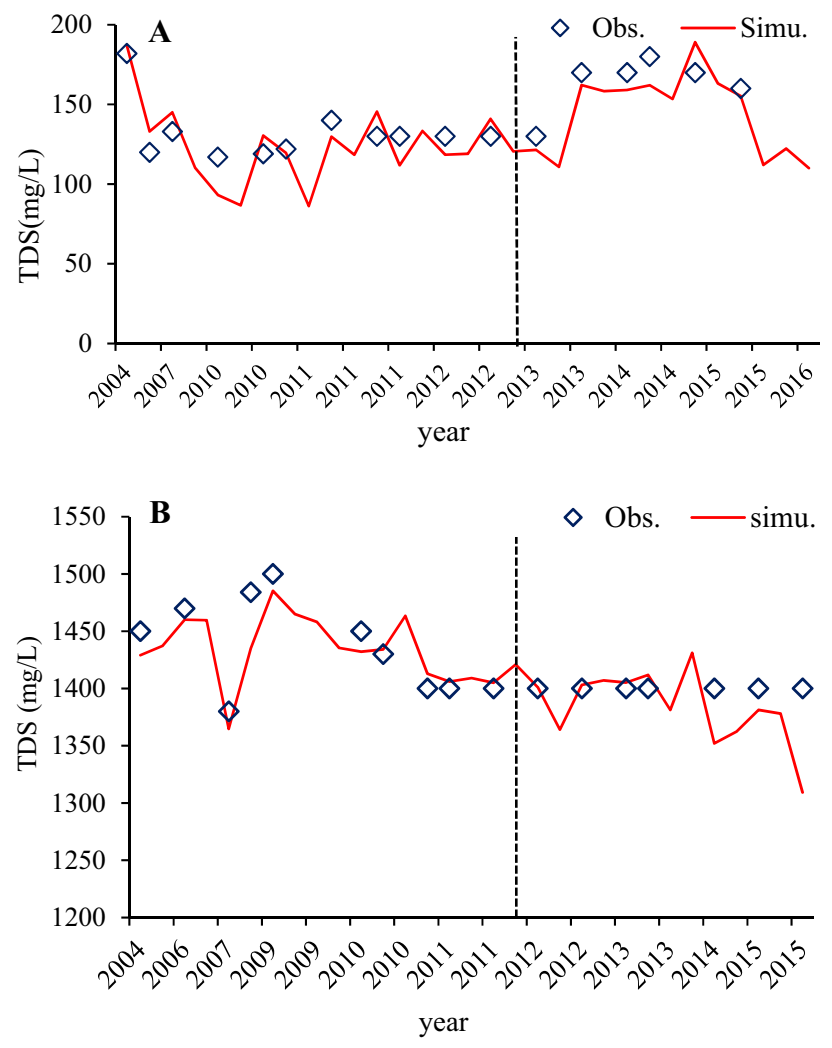

Figure 4. Comparison of daily observed and simulated groundwater quality parameter (TDS/mg/L) at IORKRL-03 (SS) (A) and IOR-KRL-04 (SS) (B) monitoring stations.

Nitrate percolation coefficient (0.223) and half-life parameter of nitrate in the shallow aquifer (116) were calibrated for each sub-basin for the values in the range of $0-1$ and $0-200$ day $^{-1}$ respectively, resulting in 0.223 and with the mean value of 116 day $^{-1}$ respectively for the whole selected ARB. The annual mean groundwater nitrate concentration is $0.31 \mathrm{mg} / \mathrm{L}$ at station IOR-KRL-03(ss) and $0.03 \mathrm{mg} / \mathrm{L}$ at station IOR-KRL-04(ss) (Fig. 3). Mineralization was adjusted by minimizing the default values of the rate factor for CMN to 0.000131 . To control the depth distribution of nitrogen uptake, and to slow down simulated kinetics, the N-UPDIS was increased from the default value of 20 to 28 and therefore a large mass of $\mathrm{NO}_{3}{ }^{-}$was removed from the upper layers as per the report by ${ }^{64,65}$. The range of nitrogen settling in reservoirs was kept constant during the year as per ${ }^{66}$, the range was set greater than the default values from the Sava River Basin, to efficiently simulate the substantial retention in major wetlands because wetland specific retention is not applied in the extended SWAT model.

The nitrification rate decreased from the upper to lower Athabasca River Basin, which mirrors the rainfall distribution, with lower rainfall leading to lower soil saturation and lower nitrification rates. The maximum values of nitrate in groundwater of the ARB were $0.62 \mathrm{mg} / \mathrm{L}$ at IOR-KRL-03(ss) and $0.1 \mathrm{mg} / \mathrm{L}$ at IOR-KRL-04(ss) stations respectively, whereas the minimum values were $0.02 \mathrm{mg} / \mathrm{L}$ at the IOR-KRL-03(ss) station and $0.01 \mathrm{mg} / \mathrm{L}$ at the IOR-KRL-04(ss) station. The nitrification calibration resulted to satisfactory predictions of $\mathrm{NO}_{3}{ }^{-}$daily concentration in the two observation stations in the calibration and validation dataset. Ae per the comparison of $\mathrm{NO}_{3}{ }^{-}$between simulated and observed, better model performances were obtained in the model evaluation dataset. The simulated daily $\mathrm{NO}_{3}{ }^{-}$concentration agreed with the observed data and were acceptable range (Fig. 3). The percentage BIAS obtained from the observed and calculated daily loads also was ranked as acceptable to very good for all the selected stations (Fig. 3 and Table 2).

Total dissolved solids (TDS). The TDS module for groundwater quality used the TDS concentrations from the selected groundwater monitoring stations in the ARB. The calibrated TDS parameters with specific ranges were presented in Table 1. Daily TDS concentrations were calibrated by adjusting the parameters related to groundwater. The model performance evaluation criteria reported by ${ }^{62}$ were used for the daily nutrient simulation as a guideline in evaluating the model performance for the daily TDS concentrations. Figure 4 shows that for the whole period of simulation, $\mathrm{R}^{2}$, NSE and PBIAS values were found to be good to very good during calibration while they were satisfactory to good during the validation (Table 2). Generally, the overall model performance for the daily TDS concentration simulations in groundwater of the ARB shows that the model could capture the observed concentrations. When comparing the calculated and observed concentrations (Fig. 4), the simulated TDS concentrations were also acceptable as both show similar trends. Yet, local inconsistencies were noticed in the river basin. The highest percentage of overestimation and underestimation of TDS in the 

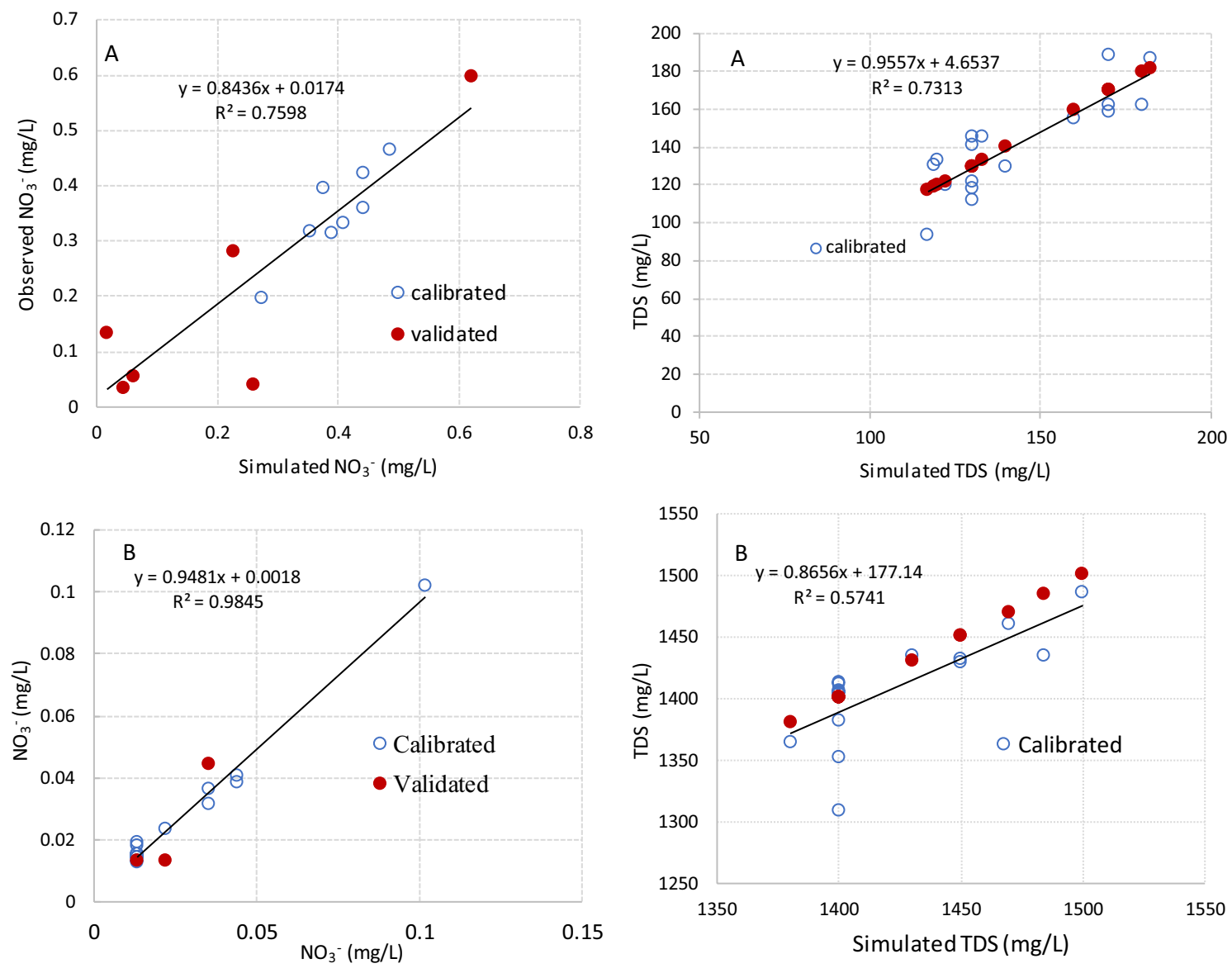

Figure 5. Scatter plot comparison between of daily simulated and observed groundwater quality parameters at IOR-KRL-03 (SS) (A) and IOR-KRL-04 (SS) (B) monitoring stations.

calibration dataset occurs for high concentration observations and probably reflects the SWAT model's representation of high level concentration ${ }^{67}$, which may cause errors in the process of calculating TDS in the SWAT model $^{68}$. The other possible sources of overestimation and underestimation of the model simulations originate from uncertainties in the input data and observed data. For example, the frequency of data collection varied from once or twice per month to once every few years. In contrast, the simulations used a daily time step. The low frequency of sampling might miss the peak or valley of nutrient concentrations.

Total Dissolved Solids is an indicator of the availability of total dissolved salt and other constituents that affect groundwater quality. High TDS concentrations in groundwater can occur naturally, and may also indicate a downward movement of leachate into groundwater ${ }^{65,69-71}$. The average TDS concentrations in groundwater in the study area are $143 \mathrm{mg} / \mathrm{L}$ and $1421 \mathrm{mg} / \mathrm{L}$ at IOR-KRL-03(ss) and IOR-KRL-03(ss) stations, respectively. The TDS of groundwater samples ranges from $120-182 \mathrm{mg} / \mathrm{L}$ at the IOR-KRL-03(ss) station, while the TDS ranges from 1380-1500 mg/L at the IOR-KRL-04(ss) station (Fig. 4). High concentrations of TDS in groundwater reduce the palpability of water for drinking and may cause gastrointestinal pain and emetic effects in humans ${ }^{67}$. TDS is an important indicator for evaluating the quality of groundwater. High levels of TDS typically occur for hard water and might require groundwater treatment to decrease concentrations below $500 \mathrm{mg} / \mathrm{L}^{67}$.

The performance of model results were investigated by using the analysis of scatter plot between observed and simulated estimates at each groundwater monitoring stations (Fig. 5). The slope at the selected stations were considerably far from zero. This showed that the model prediction accuracy was enhanced by extended groundwater model. Thus, the results of the 1:1 fitting line confirmed that the extended groundwater SWAT module was effective prediction of nutrient concentration in the groundwater. The scatters are closer to the 1:1 line for the entire study time at two monitoring stations, albeit at some points relatively far from the fitting line probably due to limited availability of observed data. In general, it is worth to conclude the extended SWAT groundwater module shows better efficiency for simulating nutrient concentrations in the groundwater.

Groundwater quality analysis and nutrient concentrations. Analysis of observed against simulated nitrate and TDS concentrations in ARB groundwater helps to identify sources of errors across two groundwater monitoring stations within the river basin. Observed nitrate concentrations vary significantly across the area (Fig. 3). Concentrations of $\mathrm{NO}_{3}{ }^{-}$in groundwater have been highly affected by emissions of both point and nonpoint sources in different watersheds across the world ${ }^{71}$. To assess pollution sources and quantify the loads of $\mathrm{NO}_{3}{ }^{-}$entering the whole river basin, $\mathrm{NO}_{3}{ }^{-}$load to groundwater has been simulated at various hydrogeological 
response units. The simulation periods were chosen based on the availability of point-source information. The long-term daily average concentrations of nitrate in groundwater attained maximum values of $0.59 \mathrm{mg} / \mathrm{L}$ at the IOR-KRL-03(ss) station during 2013. The long-term daily average concentrations of nitrate in groundwater reached a minimum of $0.025 \mathrm{mg} / \mathrm{L}$ in the year 2014 . On the other hand, at station at IORKRL-04(ss) the longterm daily average $\mathrm{NO}_{3}{ }^{-}$concentrations recorded a maximum value of $0.1 \mathrm{mg} / \mathrm{L}$ during the year 2015 , and a minimum value of $0.013 \mathrm{mg} / \mathrm{L}$ in most observation years. Generally, the concentrations of nitrate were well captured in all the groundwater monitoring stations, although some overestimations were observed at some points at IOR-KRL-04(ss) monitoring station (Fig. 3) and some underestimations were found at IOR-KRL-03(ss) and IOR-KRL-04(ss) monitoring stations. The probable reason for model overestimation is the data uncertainty such rainfall and snow distribution, in which the rainfall and snow distribution caused in nutrient concentrations. The Underestimation was probably subjected to the uncertainty of the input data and measured data. Furthermore, the observed $\mathrm{NO}_{3}{ }^{-}$data is not sufficient for continuous daily $\mathrm{NO}_{3}{ }^{-}$concentration for the entirely considered period for this study. Therefore, observed data could be sources for the errors. The simulation of $\mathrm{NO}_{3}{ }^{-}$removal by soil denitrification could be improved by varying the river basin parameters. However, the existing SWAT model could not represent perfectly the seasonal difference in nitrate concentrations. After carefully extending the model, the findings of this study highlight the need to improve spatial representation of nitrate concentrations in groundwater and in the parameters that influence nitrate concentrations at the watershed scale.

\section{Concluding remarks}

Groundwater is a precious natural resource supporting the existence of life on earth. However, various factors, such as soil properties, crop growth, industrial wastes, and agricultural management, can influence its quality. Development of industries and agriculture increase water use, which puts pressure on groundwater quality and may, in turn, influence the ecosystem of the Athabasca River Basin. Particularly, the use of fertilizers, manure, and industrial wastes may contribute to the pollution of groundwater and connected surface water environments. It is necessary to perform optimal management of groundwater resources in the basin.

State-of-the-art groundwater quality modelling at the ARB is recognized as a vital component of groundwater management, where further in-depth studies may be required to offer valuable insights related to groundwater condition and nutrient processes at the various spatio-temporal scales (i.e. site and region, and daily, monthly and annually). This can better support nutrient monitoring networks for river basin management, and enhance understanding of changing nutrient concentrations in the ARB. The SWAT model results could support the development of indicators for groundwater quality parameters, and also support integrated surface water and groundwater management. However, the accuracy of SWAT predictions is limited by data availability and structure of the model. This may result in errors while modeling processes in the river basin. For example, the highest percentage of overestimation and underestimation for TDS in the calibration dataset probably reflected the poor representation of SWAT model to high concentrations, as well as uncertainties of the input data and observed data, which in turn may cause errors in estimating groundwater TDS in the SWAT model. With continued monitoring of the groundwater network at regular frequencies, high quality input data would be available for better calibration and validation of the model. Furthermore, additional data would improve the representation of processes and pathways controlling groundwater pollution and therefore allow evaluation of the effect of land and water management practices to support the implementation of the best management practices.

In this study, we extended the existing SWAT model to improve modelling of groundwater quality (i.e. $\mathrm{NO}_{3}{ }^{-}$and TDS). A systematic calibration and validation of the SWAT model has been performed to compare the observed groundwater $\mathrm{NO}_{3}{ }^{-}$and TDS concentrations in the ARB. The results revealed that the new groundwater quality model in the SWAT is able to capture the daily nutrient concentrations in groundwater. The simulated results agree with the observed data with satisfactory and good performance for both groundwater monitoring stations as per the model performance measures. Thus, the process-based hydrologic groundwater quality model is an effective tool in simulating the groundwater quality dynamics $\left(\mathrm{NO}_{3}{ }^{-}\right.$and TDS) for sustainable groundwater and surface water management in the river basin.

Received: 18 August 2020; Accepted: 21 January 2021

Published online: 30 June 2021

\section{References}

1. Papaioannou, A. et al. Assessment and modelling of groundwater quality data by environmetric methods in the context of public health. Water Resour. Manag. 24(12), 3257-3278 (2010).

2. García-Díaz, J. C. Monitoring and forecasting nitrate concentration in the groundwater using statistical process control and time series analysis: a case study. Stoch. Env. Res. Risk Assess. 25(3), 331-339 (2011).

3. Khadri, S. F. R. \& Pande, C. Ground water flow modeling for calibrating steady state using MODFLOW software: A case study of Mahesh River basin, India. Model. Earth Syst. Environ. 2(1), 39 (2016).

4. Moharir, K., Pande, C. \& Patil, S. Inverse modelling of aquifer parameters in basaltic rock with the help of pumping test method using MODFLOW software. Geosci. Front. 8(6), 1385-1395 (2017).

5. Morris, B. L. et al. Groundwater and Its Susceptibility to Degradation: A Global Assessment of the Problem and Options for Management Vol. 3 (United Environment Programme, 2003).

6. Siebert, S. et al. Groundwater use for irrigation-A global inventory. Hydrol. Earth Syst. Sci. 14(10), 1863-1880 (2010).

7. Coynel, A., Schäfer, J., Dabrin, A., Girardot, N. \& Blanc, G. Groundwater contributions to metal transport in a small river affected by mining and smelting waste. Water Res. 41(15), 3420-3428 (2007).

8. Williams, J. R. \& Hann, R. W. Optimal Operation of Large Agricultural Watersheds with Water Quality Restraints (Texas Water Resources Institute, Berlin, 1978).

9. Almasri, M. N. Nitrate contamination of groundwater: A conceptual management framework. Environ. Impact Assess. Rev. 27(3), 220-242 (2007). 
10. Srivastava, P. K., Pandey, P. C., Kumar, P., Raghubanshi, A. S., \& Han, D. Appraisal of surface and groundwater of the Subarnarekha River Basin, Jharkhand, India: Using remote sensing, irrigation indices and statistical technique. In Geospatial Technology for Water Resource Applications 160-185 (CRC Press, 2016).

11. Singh, A. K., Patel, S., \& Singh, S. K. Groundwater quality assessment and its suitability for drinking purposes in Sonbhadra District, UP, India. In Integrated Natural Resource Management: The Way Forward (2018).

12. Jacintha, T. G. A., Rawat, K. S., Mishra, A. \& Singh, S. K. Hydrogeochemical characterization of groundwater of peninsular Indian region using multivariate statistical techniques. Appl. Water Sci. 7(6), 3001-3013 (2017).

13. Lewandowski, J., Meinikmann, K., Nützmann, G. \& Rosenberry, D. O. Groundwater-The disregarded component in lake water and nutrient budgets. Part 2: Effects of groundwater on nutrients. Hydrol. Processes 29(13), 2922-2955. https://doi.org/10.1002/ hyp.10384 (2015).

14. Nemčić-Jurec, J., Singh, S. K., Jazbec, A., Gautam, S. K. \& Kovač, I. Hydrochemical investigations of groundwater quality for drinking and irrigational purposes: two case studies of Koprivnica-Križevci County (Croatia) and district Allahabad (India). Sustain. Water Resour. Manag. 5(2), 467-490 (2019).

15. Di Curzio, D., Palmucci, W., Rusi, S. \& Signanini, P. Evaluation of processes controlling Fe and Mn contamination in the San Pedro Sula porous aquifer (North Western Honduras). Rend. Online Soc. Geol. Ital. 41, 42-45. https://doi.org/10.3301/ROL.2016. 88 (2016).

16. Oyarzun, R., Arumí, J., Salgado, L. \& Mariño, M. Sensitivity analysis and field testing of the RISK-N model in the Central Valley of Chile. Agric. Water Manag. 87(3), 251-260 (2007).

17. Srivastava, P. K., Singh, S. K., Gupta, M., Thakur, J. K. \& Mukherjee, S. Modeling impact of land use change trajectories on groundwater quality using remote sensing and GIS. Environ. Eng. Manag. J. 12(12), 2343-2355 (2013).

18. Kumar, N., Singh, S. K. \& Pandey, H. K. Drainage morphometric analysis using open access earth observation datasets in a droughtaffected part of Bundelkhand, India. Appl. Geomat. 10(3), 173-189 (2018).

19. Bhanja, S. N., Zhang, X. \& Wang, J. Estimating long-term groundwater storage and its controlling factors in Alberta, Canada. Hydrol. Earth Syst. Sci. 22, 6241-6255 (2018).

20. Moharir, K. et al. Spatial interpolation approach-based appraisal of groundwater quality of arid regions. J. Water Supply Res. Technol. AQUA 68(6), 431-447 (2019).

21. Roselló, M. P., Martinez, J. V. \& Navarro, B. A. Vulnerability of human environment to risk: Case of groundwater contamination risk. Environ. Int. 35(2), 325-335 (2009).

22. Deng, B. \& Wang, J. Saturated-unsaturated groundwater modelling using 3D Richards equation with a coordinate transform of nonorthogonal grids. Appl. Math. Model. 50, 39-52 (2017).

23. Pardo-Igúzquiza, E. et al. A parsimonious distributed model for simulating transient water flow in a high-relief karst aquifer. Hydrogeol. J. 26(8), 2617-2627 (2018).

24. Younes, A., Zaouali, J., Lehmann, F. \& Fahs, M. Sensitivity and identifiability of hydraulic and geophysical parameters from streaming potential signals in unsaturated porous media. Hydrol. Earth Syst. Sci. 22(7), 3561-3574 (2018).

25. Eckhardt, K., Haverkamp, S., Fohrer, N. \& Frede, H. G. SWAT-G, a version of SWAT99. 2 modified for application to low mountain range catchments. Phys. Chem. Earth Parts A/B/C 27(9-10), 641-644 (2002).

26. Di Curzio, D., Rusi, S. \& Signanini, P. Advanced redox zonation of the San Pedro Sula alluvial aquifer (Honduras) using data fusion and multivariate geostatistics. Sci. Total Environ. 695, 133796. https://doi.org/10.1016/j.scitotenv.2019.133796 (2019).

27. Vazquez-Amábile, G. G. \& Engel, B. A. Use of SWAT to compute groundwater table depth and streamflow in the Muscatatuck River watershed. Trans. ASAE 48(3), 991-1003 (2005).

28. Luo, Y. et al. Assessment of crop growth and soil water modules in SWAT2000 using extensive field experiment data in an irrigation district of the Yellow River basin. J. Hydrol. 352(1-2), 139-156. https://doi.org/10.1016/j.jhydrol.2008.01.003 (2008).

29. Baffaut, C. \& Benson, V. W. Modeling flow and pollutant transport in a karst watershed with SWAT. Trans. ASABE 52(2), 469-479 (2009).

30. Watson, B. M., McKeown, R. A., Putz, G. \& MacDonald, J. D. Modification of SWAT for modelling streamflow from forested watersheds on the Canadian Boreal Plain. J. Environ. Eng. Sci. 7(S1), 145-159 (2008)

31. McKeown, R., Putz, G., Arnold, J., \& Di Luzio, M. Modifications of the Soil and Water Assessment Tool (SWAT-C) for streamflow modeling in a small, forested watershed on the Canadian boreal plain. In Proceedings of 3rd International SWAT Conference 189-199 (2005).

32. Melaku, N. D. \& Wang, J. A modified SWAT module for estimating groundwater table at Lethbridge and Barons, Alberta, Canada. J. Hydrol. 575, 420-431 (2019).

33. Meshesha, T. W., Wang, J. \& Melaku, N. D. The modified Hydrological model for assessing effect of $\mathrm{pH}$ on fate and transport of Escherichia coli in the Athabasca River Basin. J. Hydrol. 582, 124513 (2020).

34. Meshesha, T. W., Wang, J. \& Melaku, N. D. Modelling spatiotemporal patterns of water quality and its impacts on aquatic ecosystem in the cold climate region of Alberta, Canada. J. Hydrol. 587, 124952 (2020).

35. Kim, N. W., Chung, I. M., Won, Y. S. \& Arnold, J. G. Development and application of the integrated SWAT-MODFLOW model. J. Hydrol. 356(1-2), 1-16 (2008).

36. Guzman, J. A. et al. A model integration framework for linking SWAT and MODFLOW. Environ. Model. Softw. 73, 103-116 (2015).

37. Nguyen, V. T. \& Dietrich, J. Modification of the SWAT model to simulate regional groundwater flow using a multicell aquifer. Hydrol. Process. 32(7), 939-953 (2018).

38. Ng, G. H. et al. GSFLOW-GRASS v1.0.0: GIS-enabled hydrologic modeling of coupled groundwater-surface-water systems. Geosci. Model Dev. 11, 4755-4777 (2018).

39. Wang, J. et al. Modelling spatio-temporal patterns of soil carbon and greenhouse gas emissions in grazing lands: Current status and prospects. Sci. Total Environ. 739, 139092 (2020).

40. AWC. State of the Watershed Report: Phase 3 - Water Quantity and Basic Water Quality in the Athabasca Watershed. Athabasca Watershed Council. (2013).

41. Arnold, J. G. et al. SWAT: model use, calibration, and validation. Am. Soc. Agric. Biol. Eng. 55(4), 1491-1508 (2012).

42. AWC. Athabasca Watershed Council-State of the Watershed Report: Phase 1. Athabasca Watershed Council, Hilton, Alberta (2011).

43. Dibike, Y., Eum, H. I. \& Prowse, T. Modelling the Athabasca watershed snow response to a changing climate. J. Hydrol. Reg. Stud. 15, 134-148. https://doi.org/10.1016/j.ejrh.2018.01.003 (2018).

44. Shrestha, N. K. \& Wang, J. Predicting sediment yield and transport dynamics of a cold climate region watershed in changing climate. Sci. Total Environ. 625, 1030-1045 (2018).

45. Shrestha, N. K., Du, X. \& Wang, J. Assessing climate change impacts on fresh water resources of the Athabasca River Basin, Canada. Sci. Total Environ. 601, 425-440 (2017).

46. Worku, T., Khare, D. \& Tripathi, S. K. Modeling runoff-sediment response to land use/land cover changes using integrated GIS and SWAT model in the Beressa watershed. Environ. Earth Sci. 76(16), 550 (2017).

47. Neitsch, S. L., Arnold, J. G., Kiniry, J. R. \& Williams, J. R. Soil and Water Assessment Tool Theoretical Documentation Version 2009 (Texas Water Resources Institute, 2011).

48. Halefom, A., Sisay, E., Khare, D., Singh, L. \& Worku, T. Hydrological modeling of urban catchment using semi-distributed model. Model. Earth Syst. Environ. 3(2), 683-692 (2017). 
49. Sisay, E., Halefom, A., Khare, D., Singh, L. \& Worku, T. Hydrological modelling of ungauged urban watershed using SWAT model. Model. Earth Syst. Environ. 3(2), 693-702 (2017).

50. Shrestha, N. K. \& Wang, J. Water quality management of a cold climate region watershed in changing climate. J. Environ. Inf. 35(1), $56-80(2020)$.

51. Melaku, N. D., Wang, J. \& Meshesha, T. W. Improving hydrologic model to predict the effect of snowpack and soil temperature on carbon dioxide emission in the cold region peatlands. J. Hydrol. 587, 124939 (2020).

52. Melaku, N. D., Shrestha, N. K., Wang, J. \& Thorman, R. Predicting nitrous oxide emissions following the application of solid manure to grassland in the United Kingdom. J. Environ. Qual. 49(1), 1-13 (2020).

53. Lam, Q. D., Schmalz, B. \& Fohrer, N. Modelling point and diffuse source pollution of nitrate in a rural lowland catchment using the SWAT model. Agric. Water Manag. 97(2), 317-325 (2010).

54. Motsinger, J., Kalita, P. \& Bhattarai, R. Analysis of best management practices implementation on water quality using the soil and water assessment tool. Water 8(4), 145 (2016).

55. Rolff, C., Almesjö, L. \& Elmgren, R. Nitrogen fixation and abundance of the diazotrophic cyanobacterium Aphanizomenon sp. in the Baltic Proper. Mar. Ecol. Prog. Ser. 332, 107-118 (2007).

56. McElroy, A.D. Loading Functions for Assessment of Water Pollution from Nonpoint Sources, Vol. 1. (US Environmental Protection Agency, Office of Research and Development, [Office of Air, Land, and Water Use], 1976)

57. Fisher, R. S., Davidson, O. B. \& Goodman, P. T. Summary and Evaluation of Groundwater Quality in the Upper Cumberland, Lower Cumberland, Green, Trade water, Tennessee, and Mississippi River Basins (Kentucky Geological Survey, University of Kentucky, 2004).

58. Shao, G., Zhang, D., Guan, Y., Xie, Y. \& Huang, F. Application of SWAT model with a modified groundwater module to the semiarid Hailiutu River Catchment, Northwest China. Sustainability 11(7), 2031 (2019).

59. Chen, H. et al. Modeling pesticide diuron loading from the San Joaquin watershed into the Sacramento-San Joaquin Delta using SWAT. Water Res. 121, 374-385 (2017).

60. Moriasi, D. N., Gitau, M. W., Pai, N. \& Daggupati, P. Hydrologic and water quality models: Performance measures and evaluation criteria. Trans. ASABE 58(6), 1763-1785 (2015).

61. Abbaspour, K. C.\& Vedjani, M. SWAT-CUP calibration and uncertainty programs for SWAT. MODSIM07: Land. Water and Environmental Management-Integrated Systems for Sustainability. Christchurch, New Zealand, 1-7 (2007)

62. Haas, M. B., Guse, B., Pfannerstill, M. \& Fohrer, N. Detection of dominant nitrate processes in ecohydrological modeling with temporal parameter sensitivity analysis. Ecol. Model. 314, 62-72 (2015).

63. Vigiak, O. et al. Modelling sediment fluxes in the Danube River Basin with SWAT. Sci. Total Environ. 599, 992-1012 (2017).

64. Longe, E. O. \& Enekwechi, L. O. Investigation on potential groundwater impacts and influence of local hydrogeology on natural attenuation of leachate at a municipal landfill. Int. J. Environ. Sci. Technol. 4(1), 133-140 (2007).

65. Mor, S., Ravindra, K., Dahiya, R. P. \& Chandra, A. Leachate characterization and assessment of groundwater pollution near municipal solid waste landfill site. Environ. Monit. Assess. 118(1-3), 435-456 (2006).

66. Shah, S. H. H., Wang, J., Hao, X. \& Thomas, B. W. Modeling the effect of salt-affected soil on water balance fluxes and nitrous oxide emission using modified DNDC. J. Environ. Manage. https://doi.org/10.1016/j.jenvman.2020.111678 (2020).

67. WHO, H.I.D.W.B. Document for Preparation of WHO Guidelines for Drinking-Water Quality. (World Health Organization (Who/ Sde/Wsh/03.04/12), Geneva, 2003).

68. Malagó, A., Bouraoui, F., Vigiak, O., Grizzetti, B. \& Pastori, M. Modelling water and nutrient fluxes in the Danube River Basin with SWAT. Sci. Total Environ. 603, 196-218 (2017).

69. Eckhardt, K., Haverkamp, S., Fohrer, N. \& Frede, H. G. SWAT-G, a version of SWAT99. 2 modified for application to low mountain range catchments. Phys Chem Earth, Parts A/B/C. 27(9-10), 641-644 (2002).

70. Wang, J., Kumar Shrestha, N., Aghajani Delavar, M., Worku Meshesha, T. \& Bhanja, S. N. Modelling watershed and river basin processes in cold climate regions: A review. Water 13(4), 518 (2021).

71. Malagó, A., Bouraoui, F., Vigiak, O., Grizzetti, B. \& Pastori, M. Modelling water and nutrient fluxes in the Danube River Basin with SWAT. Sci Total Environ 603, 196-218 (2017).

\section{Acknowledgements}

The authors acknowledge to the Alberta Economic Development and Trade for the Campus Innovates Program Research Chair for the financial support (No. RCP-12-001-BCAIP). We are grateful to thank to Dr. Diogo Sayanda, Mike Coffill and Alex Blanchette for providing the groundwater data for the Athabasca River Basin.

\section{Author contributions}

T.W.M.: conceptualization, data curation, formal analysis, Investigation, methodology, project administration, resources, software, validation, visualization, writing — original draft, writing — review and editing. J.W.: conceptualization, data curation, formal analysis, funding acquisition, investigation, methodology, project administration, resources, software, supervision, validation, writing - review and editing. N.D.M.: data curation, formal analysis, software, validation, visualization, writing—review and editing. C.N.M.: data curation, formal analysis, review and editing.

\section{Competing interests}

The authors declare no competing interests.

\section{Additional information}

Correspondence and requests for materials should be addressed to J.W.

Reprints and permissions information is available at www.nature.com/reprints.

Publisher's note Springer Nature remains neutral with regard to jurisdictional claims in published maps and institutional affiliations. 
(c) (i) Open Access This article is licensed under a Creative Commons Attribution 4.0 International cc) License, which permits use, sharing, adaptation, distribution and reproduction in any medium or format, as long as you give appropriate credit to the original author(s) and the source, provide a link to the Creative Commons licence, and indicate if changes were made. The images or other third party material in this article are included in the article's Creative Commons licence, unless indicated otherwise in a credit line to the material. If material is not included in the article's Creative Commons licence and your intended use is not permitted by statutory regulation or exceeds the permitted use, you will need to obtain permission directly from the copyright holder. To view a copy of this licence, visit http://creativecommons.org/licenses/by/4.0/.

(C) The Author(s) 2021, corrected publication 2022 